\title{
Analisis Profil Protein dan Asam Amino Sarang Burung Walet (Collocalia fuchiphaga)Asal Painan
}

\author{
Lina Elfita \\ Program Studi Farmasi, Fakultas Kedokteran dan Ilmu Kesehatan, \\ UIN Syarif Hidayatullah, Jakarta \\ Email: linaelvita@gmail.com
}

\begin{abstract}
Abstrak
Penelitian tentang profil protein sarang burung wallet masih terbatas, terutama sarang burung walet dari Indonesia. Oleh karena itu, penelitian ini bertujuan untuk menganalisa profil protein dan asam amino sarang burung walet yang berasal dari daerah Painan, Kabupaten Pesisir Selatan, Sumatera Barat. Analisis protein dilakukan dengan menggunakan SDS-PAGE, sedangkan analisis asam amino dilakukan dengan menggunakan kromatografi cair kinerja tinggi (KCKT). Analisa ekstrak air sarang burung walet dengan SDS-PAGE menunjukan bahwa sarang burung walet terdiri dari 6 protein. Keenam protein tersebut mempunyai bobot molekul masing-masing 147.2 $\mathrm{kDa}, 142.6 \mathrm{kDa}, 133.4 \mathrm{kDa}, 73.3 \mathrm{kDa}, 66.2 \mathrm{kDa}$ dan $37.7 \mathrm{kDa}$. Dari analisa asam amino burung walet dengan KCKT didapatkan 16 asam amino yang terkandung dalam sarang burung wallet, yang terdiri dari 7 jenis asam amino esensial yaitu Histidin (2.31\%), Leusin (3.84\%), Treonin (3.82\%), Valin (3.93\%), Metionin (0.48\%), Isoleusin (1.80\%), Fenilalanine $(4.49 \%)$ dan 9 asam amino non esensial yaitu Asam Serin (4.56\%), Aspartat (4.48\%), Arginin (3.93\%), Lisin (2.34 \%), Prolin (3.64\%), Asam glutamate (3.65\%), Glisin (1.87\%), Alanin (1.31\%), Tirosin $(3.92 \%)$. Serin merupakan asam amino dengan kadar tertinggi (4.56\%), diikuti dengan Fenil alanine (4.49\%) dan Asam aspartate $(4.48 \%)$. Kandungan asam amino ini sedikit berbeda dengan kandungan asam amino sarang burung walet dari daerah dan negara lain.
\end{abstract}

Kata kunci: sarang burung walet, protein, asam amino

\begin{abstract}
Study on protein profile of bird nest is still limited particularly protein profile of bird nest from Indonesia has not been reported. Therefore, this study was aimed to analyze protein profile and amino acid composition of bird nest from Painan, Pesisir Selatan Distric, West Sumatra. Protein analysis was performed by SDS-PAGE, and high performance liquid chromatography (HPLC) was used for amino acid analysis. SDS-PAGE analysis showed six bands, which molecular weigh of 147.2 kDa, $142.6 \mathrm{kDa}, 133.4 \mathrm{kDa}, 73.3 \mathrm{kDa}, 66.2 \mathrm{kDa}$ and $37.7 \mathrm{kDa}$, respectively. On the other hand, HPLC analysis demonstrated that bird nest was composed of 16 amino acids. Seven of them were essential amino acids; histidine $(2.31 \%)$, leucine $(3.84 \%)$, threonine $(3.82 \%)$, valine $(3.93 \%)$, methionine $(0.48 \%)$, isoleucine $(1.80 \%)$, phenylalanine $(4.49 \%)$, and nine of them were non-essential amino acids; serine $(4.56 \%)$, aspartic acid $(4.48 \%)$, arginine $(3.93 \%)$, lysine $(2.34 \%)$, proline $(3.64 \%)$, glutamic acid $(3.65 \%)$, glycine $(1.87 \%)$, alanine $(1.31 \%)$, tyrosine $(3.92 \%)$. Serine was the highest percentage of amino acid in the bird nest (4.56\%), followed by phenylalanine $(4.49 \%)$ and aspartic acid $(4.48 \%)$. Composition of amino acid in this bird nest was slightly different with composition of amino acid in bird nest from other area.
\end{abstract}

Keywords : bird nest, protein profile, amino acids

\section{PENDAHULUAN}

Walet (collocaliini) adalah burung pemakan serangga yang bermigrasi dari Samudera Hindia melaui Asia Tenggara dan
Australia utara hingga ke Samudra pasifik. Diantara berbagai jenis wallet dalam genus Collacalia, hanya sarang dari empat spesies yang berhabitat di Asia Tenggara yang mempunyai nilai komersial. karena di 
konsumsi oleh manusia, yaitu Collocalia fuchiphaga, Collocalia germanis, Collocalia maxima dan Collocalia unicolor. Sarang burung wallet yang harganya mahal dibuat dari air liur yang dihasilkan oleh jenis burung Collocalia fuchiphaga (sarang putih) dan Collocalia maxima (sarang hitam). Meskipun habitat alami burung wallet adalah gua-gua kapur, Collocalia fuchiphaga telah berhasil "ditangkarkan" dalam rumah-rumah sejak tahun 1880. Produksi sarang wallet terbesar di Indonesia adalah Jawa tengah menyusul Jawa timur dan Jawa Barat (Mardiastuti, 1997).

Sarang burung wallet ini dianggap mempunyai banyak khasiat dan mempunyai rasa yang sangat lezat. Dalam komunitas Tionghoa, sarang burung wallet diyakini mempunyai manfaat kesehatan seperti sebagai anti aging, promosi pertumbuhan dan meningkatkan sistem imun. Sarang burung wallet tidak hanya digunakan sebagai obat, tetapi juga makanan yang lezat. Secara tradisional, sarang burung wallet direbus dengan gula batu untuk menghasilkan makanan yang lezat yang dikenal sebagai "sup sarang burung" (Chan, 2010).

Sarang burung wallet mengandung glikoprotein, karbohidrat, asam amino dan garam-garam mineral. Karbohidrat yang utama terdapat pada sarang burung wallet adalah asam sialat (9\%), galaktosamin (7.2\%), glukosamin $(5.3 \%)$, galaktosa $(16.9 \%)$ dan fucosa (0.7\%) (Ramli \& Azmi, 2012; Colombo et al., 2003). Menurut Sam et al. (1991) yang disampaikan oleh Ramli dan Azmi (2012) menyatakan asam amino dan garam-garam mineral juga terdapat dalam sarang burung wallet, garam mineral utama yaitu natrium dan kalsium, dalam jumlah sedikit magnesium, seng, mangan dan besi. Menurut Kathan dan Weeks (1969), ditemukan tiga asam amino non essensial (asam aspartat, asam glutamate dan prolin) dan dua asam amino non essensial (treonin dan valin) dalam sarang burung wallet. Marcone (2005) melaporkan bahwa komposisi kimia sarang burung wallet putih dan hitam adalah identik yaitu lemak (0.14$1.28 \%)$, abu (2.1\%), karbohidrat (25.62$27.26 \%$ ) dan protein $(62-63 \%)$.

Terlepas dari sejarah panjang penggunaan sarang burung wallet untuk tujuan terapi, sedikit sekali literatur penelitian ilmiah yang berkaitan dengan penggunaan sarang burung wallet untuk terapi. Bukti ilmiah pertama dipublikasikan oleh $\mathrm{Ng}$ et al., (1986) yang menyatakan bahwa ekstrak air sarang burung wallet dapat mempotensiasi respon mitogenik monosit darah perifer manusia terhadap rangsangan dengan agent proliferatif concavanalin A dan phytohemagglutinin A. Hal ini menunjukkan bahwa sarang burung wallet mempunyai efek meningkatkan system imum dengan membantu pembelahan sel-sel system imun. Penelitian yang dilakukan oleh Abidin et al., (2011) melaporkan bahwa pada konsentrasi rendah sarang burung wallet dapat memproliferasi sel secara sinergis terutama dalam serum yang mengandung media. Ini dapat menjadi terobosan baru sebagai proliferasi sel dan pemeliharaan fungsional yang penting selama penyembuhan luka di kornea. Studi mengenai efek sarang burung wallet pada sel usus yang menggunakan sel line Caco-2 menunjukkan proliferasi tertinggi dalam sarang burung komersial di bandingkan dengan sarang burung yang tidak diproses yang diperoleh dari empat zona yang berbeda dari semenanjung Malaysia (Aswir dan Wan Nazaimoon, 2010).

Meskipun protein merupakan komposisi utama dari sarang burung wallet, namun sangat sedikit sekali penelitian ilmiah yang fokus pada profil protein sarang burung wallet mengingat adanya variasi jenis sarang wallet yang beragam. Namun sampai saat ini belum ada peneliti di Indonesia yang meneliti tentang analisis profil protein dan asam amino dari sarang burung wallet. Oleh karena itu perlu dilakukan penelitian tentang analisis profil protein dan asam amino dari sarang burung wallet yang berasal dari daerah Painan, Kabupaten Pesisir Selatan, Provinsi Sumatera Barat. Diharapkan hasil penelitian ini dapat menjadi acuan untuk penelitian sarang burung wallet selanjutnya. Sehingga ke depannya dapat dijadikan patokan dalam pemilihan kualitas dari sarang burung wallet. Analisis protein dilakukan dengan menggunakan SDSPAGE (Liu et al., 2012; Marcone, 2005). Analisis profil protein yang dilakukan meliputi penentuan kadar dan bobot molekul protein, sedangkan analisis asam amino dilakukan dengan menggunakan HPLC (Utami, 2012; Rutherfurd and Dunn, 2011). Analisis asam amino yang dilakukan meliputi komposisi asam amino dan persentase asam amino tersebut yang terdapat dalam sarang burung wallet. 


\section{METODE PENELITIAN}

\section{Alat dan Bahan}

Alat-alat yang digunakan adalah satu set elektroforesis, satu set perangkat HPLC, Spektrofotometer UV-Vis, Sentrifuge, Mikro pipet dan tip, kantung dialysis 3500 comw, vortex, Homogenizer, Sonicator, Tanur, neraca analitik, Mortar dan stamper.

Bahan yang digunakan adalah sarang burung wallet yang diperoleh dari Painan (Sumatera Barat), Marker protein $250 \mathrm{kDa}$ [Biorad], BSA (Bovine Serum Albumin), Coommassie Briliant Blue, larutan 30\% akrilamid $/ 0.8 \%$ bisakrilamid, buffer Tris- $\mathrm{HCl}$, APS, TEMED, Ortoftalaldehid, standar asam amino, bufer borat, merkaptoetanol, aquabidest.

\section{Ekstraksi Protein Sarang Burung Walet}

Sarang wallet yang telah dipanen (usia 20 hari), diangin-anginkan selama satu minggu. Lima gram sarang wallet dihaluskan menggunakan mortar. Satu gram sarang wallet yang telah dihaluskan dilarutkan dalam $50 \mathrm{ml}$ aquabidest dan dihomogenkan dengan homogenizer selama 30 menit. Selanjutnya di sentrifuge pada $10000 \mathrm{rpm}$ selama 10 menit. Supernatan di masukkan ke dalam kantung dialysis 3500 cut-off molecular weight dan dialysis semalam. Supernatan hasil dialysis kemudian di freeze dry (Liu et al., 2012).

\section{Pengukuran Kadar Protein dengan Metode Semi mikro Kjeldahl}

Sebanyak 0.51 gram sarang burung wallet yang telah dihaluskan ditimbang. Kemudian masukkan ke dalam labu kjeldahl $100 \mathrm{ml}$. Dua gram campuran selen dan $25 \mathrm{ml}$ H2SO4 pekat di tambahkan ke dalam labu kjeldahl yang telah berisi sampel. Dipanaskan sampai mendidih dan larutan menjadi jernih kehijauan $( \pm 2$ jam), kemudian didinginkan dan dimasukkan ke dalam labu ukur $100 \mathrm{ml}$, diencerkan dengan aquabidest sampai tanda batas. Pipet $5 \mathrm{ml}$ ke labu destilasi, ditambahkan $5 \mathrm{ml} \mathrm{NaOH} 30 \%$ dan 3 tetes indicator PP. Destilasi selama 10 menit. Destilat ditampung $10 \mathrm{ml}$ dengan asam borat $2 \%$ dan indicator campuran (BCG + metil red).

\section{Analisis Profil Protein (Metode SDS-PAGE)}

Elektroforesis dilakukan berdasarkan metode Laemmli (Coligan et al., 1997). Gel poliakrilamid dicetak diantara lempengan kaca. Larutan separating gel 12\% yang telah di siapkan langsung di masukkan ke dalam cetakan gel dengan menggunakan mikropipet sampai batas tertentu. Setelah gel mengeras, larutan stacking gel mulai disiapkan dan dimasukkan ke dalam cetakan, permukaan gel di tutup dengan sisir lalu di biarkan sampai stacking gel mengeras. Cetakan gel di pindahkan ke wadah elektroforesis. Sebanyak $10 \mu \mathrm{l}$ seri dilusi larutan sampel $(1: 2 ; 2: 1,3: 1$; 4:1) dan $4 \mu \mathrm{l}$ marker protein di masukkan ke dalam masing-masing sumur gel. Elektroforesis di nyalakan sampai pewarna mencapai ujung gel ( \pm 1 jam). Gel di lepaskan dari cetakan, kemudian di rendam dalam larutan pewarna Coommasie brilliant blue selama semalam sambil di goyangkan menggunakan shaker. Lalu gel di cuci dengan larutan destaining masing-masing 15 menit. Setelah pita terlihat, gel di cuci dengan aquadest. Identifikasi dan analisis pola SDSPAGE di lakukan dengan membandingkan pita protein sampel dengan protein standar. Bobot molekul dari masing-masing protein di tentukan dengan cara menghitung nilai $\mathrm{Rf}$ dari masing-masing pita protein yang tampak. Kemudian di buat kurva standar hubungan antara log BM dengan Rf dari protein standar sehingga nilai $\mathrm{BM}$ protein sampel dapat di hitung.

\section{Analisis Asam Amino Larutan Standar}

Standar mix asam amino di pipet sebanyak $40 \mu \mathrm{l}$, lalu di tambahkan $40 \mu \mathrm{l}$ internal standar AABA dan $920 \mu \mathrm{l}$ aquabidest dan di homogenkan. Pipet $10 \mu \mathrm{l}$ standard, kemudian tambahkan $70 \mu \mathrm{l}$ AccQ-Fluor Borat, dan di vortex. Sebanyak $20 \mu \mathrm{l}$ reagen fluor A, dan di vortex, diamkan 1 menit. Inkubasi pada suhu $55^{\circ} \mathrm{C}$ selama 10 menit. Suntikkan pada HPLC sebanyak $5 \mu$ l.

\section{Analisis Asam Amino Sarang Burung Walet}

Sampel di timbang sebanyak $0.1 \mathrm{~g}$ dalam tabung reaksi bertutup, lalu di tambahkan $5 \mathrm{ml} \mathrm{HCl} 6 \mathrm{~N}$ dan di vortex. Sampel di aliri gas nitrogen. Selanjutnya tabung yang berisi sampel di masukkan ke dalam oven suhu $110^{\circ} \mathrm{C}$ selama 22 jam. 
Setelah dingin, dipindahkan ke dalam labu ukur $50 \mathrm{ml}$ dan ditambahkan aquabidest sampai tanda batas. Sampel di saring dengan membran filter berukuran $0,45 \mathrm{~m}$. Filtrat di pipet sebanyak $500 \mu$ l dan di tambahkan $40 \quad 1$ AABA dan 4601 aquabidest. Sebanyak 101 larutan dipipet dan ditambahkan $70 \mu \mathrm{l}$ AccQFluor Borat, kemudian di vortex. Selanjutnya ke dalam campuran tersebut di tambahkan 20 $\mu \mathrm{l}$ reagent fluor $\mathrm{A}$ dan di vortex, diamkan selama 1 menit. Inkubasi pada suhu $55^{\circ} \mathrm{C}$ selama 10 menit. Sebanyak 51 larutan sampel di injeksikan ke dalam kolom HPLC (Utami, 2012; Rutherfurd \& Dunn, 2011).

Konsentrasi asam amino dalam sampel:

mol $\mathrm{AA}=$ luas puncak sampel $\mathrm{x}$ konsentrasi standar $\mathrm{x}$ Volume Luas puncak standar

$\% \mathrm{AA}=\frac{\operatorname{mol} \mathrm{AA} \times \mathrm{Mr} \mathrm{AA}}{\mathrm{A}} 100$

g sampel

\section{HASIL DAN PEMBAHASAN}

Analisis profil protein dari sarang burung walet (Collocalia fuciphaga) telah dilakukan. Sarang burung Walet yang digunakan dalam penelitian ini berasal dari daerah Painan, Sumatera Barat. Sarang walet yang digunakan merupakan sarang dari burung Walet (Collocalia fuciphaga) yang telah di tangkarkan pada rumah-rumah Walet. Analisis profil protein dari sarang burung walet dilakukan menggunakan sodium dodecyl sulfat poliakrilamid gel elektroforesis (SDS-PAGE).

Metode ini merupakan metode yang banyak digunakan. Pada penelitian ini digunakan 2 jenis gel, yaitu gel penahan (stacking gel) dan gel pemisah (separating gel). Gel tersebut mengandung akrilamida, sodium dodecyl sulfat (SDS), amonium persulfat (APS) dan TEMED. Gel akrilamid diperoleh dengan cara polimerisasi akrilamida dengan sejumlah crosslinking agent metilen bis akrilamid dan amonium persulfat (APS) sebagai katalisator. Radikal bebas yang terbentuk dari pelarutan APS dalam air akan bereaksi dengan akrilamid membentuk akrilamid aktif yang dapat bereaksi satu dengan yang lain membentuk polimer (Jansen dan Ryden, 1998). Penambahan SDS bertujuan agar bagian hidrofob dari molekul protein terikat dengan SDS sehingga molekul terurai dari lipatannya. Dengan demikian proses pemisahan protein hanya berdasarkan perbedaan bobot molekul. Disamping itu ke dalam buffer sampel ditambahkan agent pereduksi yaitu $\beta$-mercaptoetanol untuk memutuskan ikatan disulfida dari protein. Pada proses elektroforesis molekul protein yang berukuran kecil akan bergerak lebih cepat melintasi gel, sedangkan molekul protein yang berukuran besar akan bergerak lebih lambat. Pada akhirnya protein dengan berat molekul yang rendah akan mempunyai Rf (jarak tempuh) yang lebih tinggi dibandingkan dengan yang berukuran lebih besar.

Gel Poliakrilamid yang digunakan dalam penelitian ini dibuat dengan konsentrasi $12 \%$. Hal ini berbeda dengan yang dilakukan oleh Liu et al. (2012) yang menganalisis profil proteomic dari sarang burung Walet menggunakan SDS-PAGE dengan konsentrasi akrilamida $10 \%$. Visualisasi SDS-PAGE dilakukan dengan menggunakan pewarnaan Coommassie Briliant Blue. Coomassie Briliant Blue staining adalah metode yang umum digunakan untuk deteksi protein dalam gel dengan fiksasi. Menurut Coligan et al. (1997), Coomassie blue staining mempunyai sensitivitas 0.05-0.5 $\mu \mathrm{g}$ protein per band. Coomassie blue berikatan secara nonspesifik dengan protein. Hasil analisis protein dengan SDS-PAGE dapat di lihat pada Gambar 1.

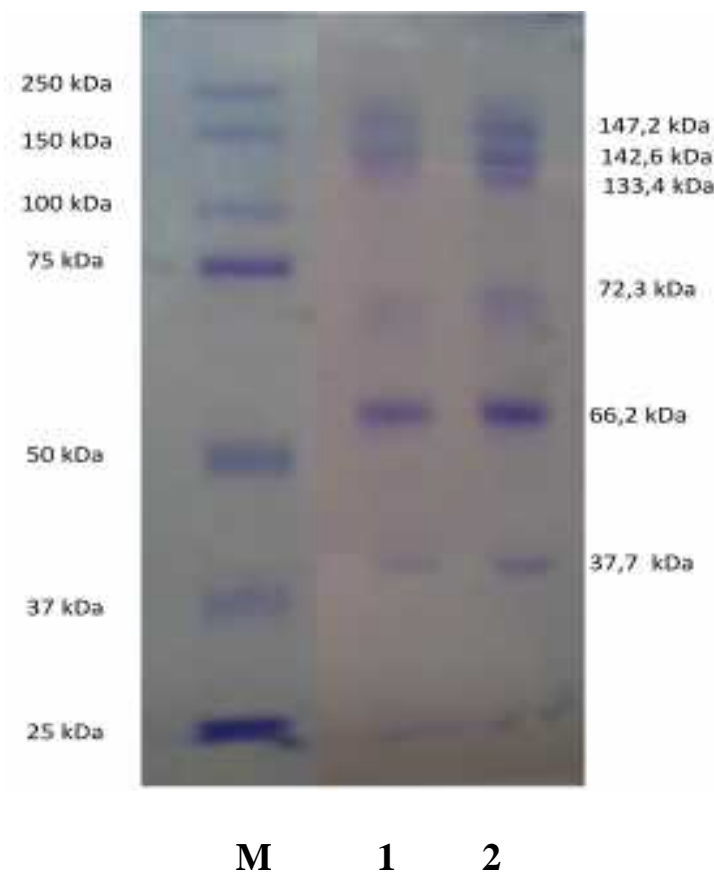

Gambar 1. Hasil Analisis SDS-PAGE Sarang burung Walet (Colocalia fuciphaga) dengan konsentrasi gel akrilamid $12 \%$ 
Keterangan :

M : Protein marker

$1 \& 2$ : Sampel sarang burung walet

Berdasarkan Gambar 1 di atas dapat di ketahui bahwa pada ekstrak air sarang burung walet terdapat 6 pita protein. Keenam pita protein tersebut mempunyai bobot molekul masing-masing $147.2 \mathrm{kDa}, 142.6 \mathrm{kDa}, 133.4$ $\mathrm{kDa}, 73.3 \mathrm{kDa}, 66.2 \mathrm{kDa}$ dan $37.7 \mathrm{kDa}$. Perhitungan bobot molekul relatif protein dari sarang walet (Collocalia fuciphaga) dilakukan dengan menggunakan kurva standar bobot molekul relatif seperti yang di sajikan pada Tabel 1 dan Gambar 2. Sebagai molekul pembanding (marker protein) digunakan Precision Plus Protein Standards (Bio-Rad) dengan ukuran $250 \mathrm{kDa}-10 \mathrm{kDa}$. Protein dengan bobot molekul $56.49 \mathrm{kDa}$ memperlihatkan pita protein yang tebal. Ketebalan pita menunjukkan konsentrasi protein yang tinggi (Gambar 1).

Tabel 1. Penentuan Bobot Molekul Sarang Burung Walet (Collocalia fuciphaga)

\begin{tabular}{cccccc}
\hline $\begin{array}{c}\text { BM Marker } \\
\text { Protein }(\mathrm{kDa})\end{array}$ & $\begin{array}{c}\text { Log BM } \\
\text { Marker Protein }\end{array}$ & $\begin{array}{c}\text { Rf Marker } \\
\text { Protein }\end{array}$ & Rf Sampel & $\begin{array}{c}\text { Log BM } \\
\text { Sampel }\end{array}$ & $\begin{array}{c}\text { BM Sampel } \\
(\mathrm{kDa})\end{array}$ \\
\hline 250 & 2.398 & 0.114 & 0.186 & 2.168 & 147.231 \\
150 & 2.176 & 0.171 & 0.200 & 2.154 & 142.561 \\
100 & 2.000 & 0.286 & 0.229 & 2.125 & 133.352 \\
75 & 1.875 & 0.357 & 0.486 & 1.865 & 73.282 \\
50 & 1.699 & 0.614 & 0.529 & 1.821 & 66.221 \\
37 & 1.568 & 0.814 & 0.771 & 1.576 & 37.670 \\
25 & 1.398 & 0.986 & & & \\
\hline
\end{tabular}

Berdasarkan data di atas dapat di ketahui bahwa bobot molekul protein dari ekstrak air sarang burung wallet (Collocalia fuciphaga) asal painan berkisar antara 147 kDa-37 kDa. Sementara Liu et al. (2012) yang menganalisis profil protein dari sarang burung wallet asal Malaysia, Indonesia, Thailand dan Vietnam menggunakan SDS-PAGE dua dimensi melaporkan bahwa distribusi bobot molekul protein sarang burung wallet dari beberapa wilayah tersebut berkisar antara 100 kDa -20 kDa.

Pada penelitian ini, digunakan metode semi-mikro Kjeldahl untuk menganalisis kadar protein dari sarang wallet. Hasil analisis protein menggunakan metode semi-mikro Kjeldahl didapatkan kadar protein sebesar 55.62\%. Zaenab et al. (2013) melaporkan bahwa kandungan protein sarang burung wallet dari beberapa wilayah di Malaysia, Thailand, Vietnam dan Indonesia berkisar antara 59,865.4\%. Qin et al. (2000) melaporkan bahwa kadar protein sarang burung wallet asal Cina berkisar antara 50-60\%. Cara Kjeldahl digunakan untuk menganalisis kadar protein kasar dalam bahan makanan secara tidak langsung, karena yang dianalisis adalah kadar nitrogennya (Mc. Donald, 1977). Prinsip kerja analisis metode Kjeldahl adalah mula-mula dengan mendestruksi sampel dengan asam sulfat pekat menggunakan katalis selenium oksiklorida atau butiran $\mathrm{Zn}$, sehingga dihasilkan ammonium sulfat, kemudian ammonia yang terjadi ditampung dan dititrasi dengan bantuan indikator. Dengan mengalikan hasil analisis tersebut dengan angka konversi 6.25 maka diperolleh kadar protein dari sampel tersebut. Cara analisis Kjeldahl pada umumnya dibagi menjadi 2 tipe yaitu makro Kjeldahl dan semi-mikro Kjeldahl. Pada penelitian ini digunakan metode semi-mikro Kjeldahl. Metode semi mikro Kjeldahl ini sangat cocok digunakan untuk bahan sampel yang sedikit dan kurang dari $300 \mathrm{mg}$ dari bahan yang homogen. Selain itu, metode semi-mikro Kjeldahl memerlukan waktu analisis yang lebih singkat dan biaya yang lebih rendah 
dibandingkan dengan metode Kjeldahl yang konvensional (Manefee and Overman, 1940).

Oleh karena protein dalam sarang burung wallet (Collocalia fuciphaga) mempunyai kadar yang tinggi, maka data yang digunakan adalah data hasil analisis kadar protein dengan menggunakan metode semi mikro Kjeldahl. Berdasarkan hasil analisis kadar protein menggunakan metode semi mikro kjeldahl didapatkan kadar protein dari sarang burung wallet adalah 55.62\%. Hasil yang di dapatkan tidak berbeda secara significan dengan kadar protein yang dilaporkan oleh Zaenal et al. (2013) dan Qin et al. (2000).

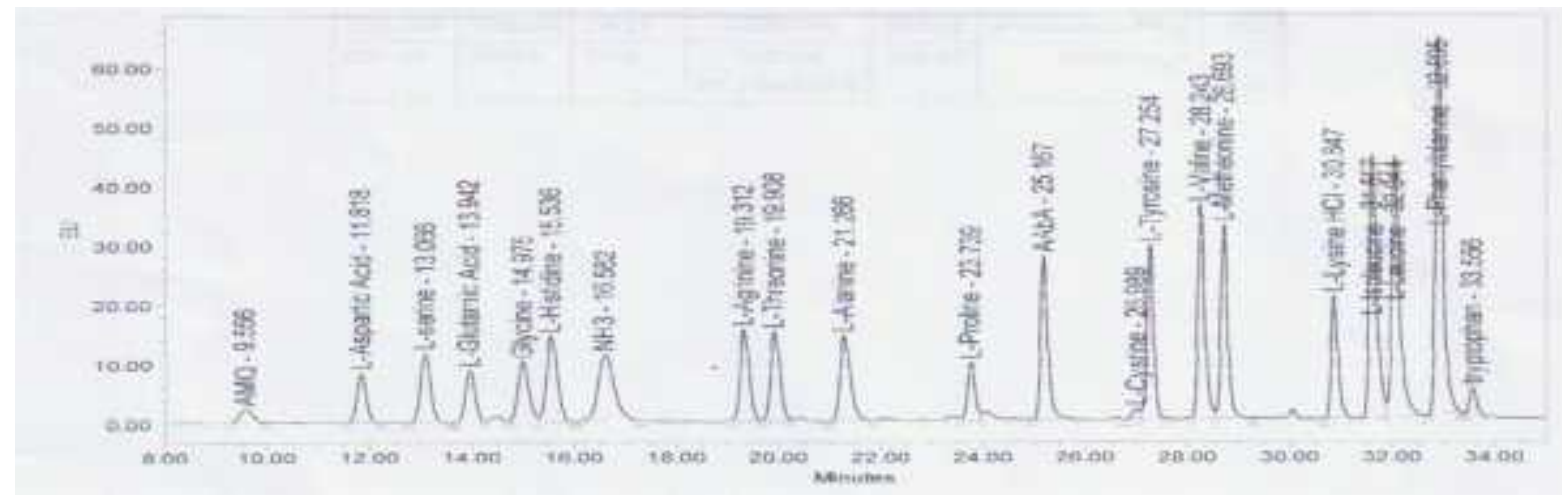

Gambar 2. Kromatogram asam amino standar

Analisis asam amino dari sarang burung wallet (Collocalia fuciphaga) dilakukan dengan menggunakan Kromatografi Cair Kinerja Tinggi (KCKT). Analisis asam amino sangat penting dilakukan, karena kualitas protein suatu bahan pangan sangat ditentukan oleh kadar asam amino yang dikandungnya. Dari segi nutrisi asam amino dibagi menjadi 2 golongan, yaitu asam amino non essensial dan asam amino essensial. Asam amino non esensial adalah asam amino yang dapat disediakan oleh tubuh organisme melalui proses biosintesa yang rumit dari senyawa nitrogen yang terdapat dalam makanan, dan asam amino esensial, adalah asam amino yang tidak dapat disintesa oleh tubuh. Untuk memenuhi kebutuhan protein, suatu organisme memerlukan tambahan asam amino esensial yang diperoleh dari bahan pangan atau pakan yang dikonsumsi. Banyak kelainan yang timbul terhadap manusia yang kekurangan protein. Untuk meningkatkan kadar HB pada penderita anemia, diperlukan makanan dengan gizi yang lebih baik, artinya perlu tambahan protein hewani maupun nabati, walaupun pemberian susu untuk diminum sedikit menaikkan status tersebut (Latupeirissa et al., 2000). Sekurang-kurangnya, terdapat lima belas macam asam amino esensial yang harus tersedia dalam makanan, yaitu fenilalanin, tirosin, isoleusin, lisin, metionin, sistin, treonin, valin, triptofan, arginin, histidin, glisin, serin, asparagin, dan prolin.

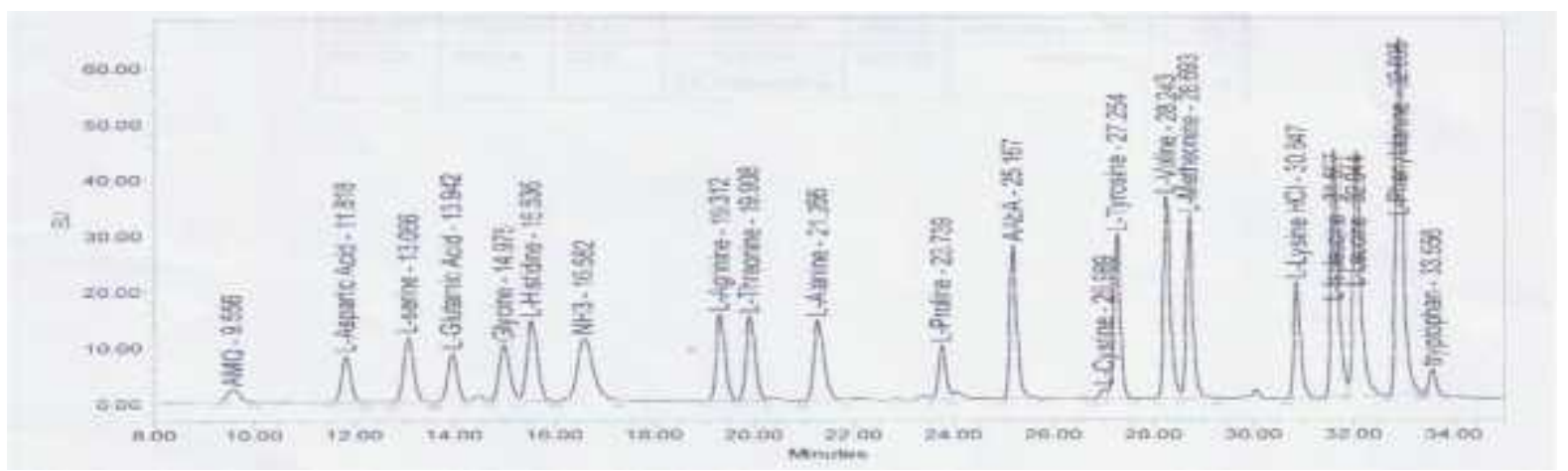

Gambar 3.Kromatogram Asam Amino Sarang Burung Walet 
Hidrolisis rantai polipeptida yang sempurna dilakukan dengan asam $\mathrm{HCl} 6 \mathrm{~N}$ berlebihan Triptofan tidak stabil dalam lingkungan asam, sehingga rusak dalam hidrolisis asam. Dengan hidrolisis asam ini serin dan threonin akan mengalami kerusakan sebagian, sedangkan asparagin dan glutamin akan terhidrolisa sempurna menjadi asam aspartat dan asam glutamat dengan membebaskan ion amonium (Linder, 1992). Kualitas nutrisi suatu protein bahan pangan ditentukan oleh kesesuaian antara jenis dan jumlah asam amino yang terkandung dengan jenis dan jumlah asam amino yang dibutuhkan; mendorong untuk dilakukannya pengembangan metoda analisis asam amino (Sumarno et al., 2002).

Pada penelitian ini didapatkan 17 asam amino yang terkandung dalam sarang burung wallet (Collocalia fuchipaga) seperti yang tampak pada Tabel 2 dan 3. Dari Tabel 3 dapat diketahui bahwa terdapat 7 jenis asam amino essensial yang terkandung dalam sarang burung wallet (Collocalia fuciphaga) yaitu histidin (2.309\%), Leusin (3.839\%), Treonin $(3.819 \%)$, Valin $(3.931 \%)$, Metionin $(0.482 \%)$, Isoleusin $(1,796 \%)$, Fenil alanine $(4.486 \%)$ dan 9 asam amino non essensial yaitu Asam Serin $(4.556 \%)$, aspartate $(4.480 \%)$, Arginin $(3.929 \%)$, Lisin $(2.343 \%)$, Prolin $(3.637 \%)$, Asam glutamate $(3.647 \%)$, glisin $(1.868 \%)$, Alanin (1.309\%), Tirosin (3,918\%). Serin merupakan asam amino dengan kadar tertinggi $(4.556 \%)$, diikuti dengan Fenil alanine $(4.486 \%)$ dan Asam aspartate $(4.480 \%)$, dan yang terendah adalah metionin $(0.482 \%)$.

Roh et al. (2012) melaporkan bahwa terdapat 8 jenis asam amino essensial dan 9 jenis asam amino non essensial pada sarang burung walet asal Xiemen, Cina. Kandungan asam amino tertinggi adalah asam asam glutamat $(51.78 \mathrm{mg} / \mathrm{g})$ dan diikuti oleh sistein $(41.06 \mathrm{mg} / \mathrm{g})$ dan asam aspartat $(40.44 \mathrm{mg} / \mathrm{g})$. Sementara itu, kandungan asam amino yang terendah adalah metionin $(5.77 \mathrm{mg} / \mathrm{g})$.

Tabel 2. Hasil Analisis Asam Amino Menggunakan KCKT

\begin{tabular}{lccccc}
\hline \multicolumn{1}{c}{ Analit } & RT & Cstd & BM & Area std & Area sampel \\
\hline AMQ & 9.548 & & & 425604 & 409150 \\
L-Asam Aspartat & 11.803 & 100 & 133.1 & 1059454 & 3218894 \\
L-Serin & 13.053 & 100 & 105.09 & 1599692 & 6259916 \\
L-Asam glutamat & 13.943 & 100 & 147.13 & 1165602 & 2608220 \\
Glisin & 14.970 & 100 & 75.07 & 1518272 & 3411216 \\
L-Histidin & 15.530 & 100 & 155.16 & 2105402 & 2828398 \\
NH3 & 16.577 & & & 2470709 & 7119930 \\
L-Arginin & 19.307 & 100 & 174.29 & 1937606 & 3942619 \\
L-Treonin & 19.905 & 100 & 119.12 & 1941740 & 5620290 \\
L-Alanin & 21.259 & 100 & 89.1 & 2050317 & 2720286 \\
L-Prolin & 23.735 & 100 & 115.13 & 1004881 & 2865489 \\
AABA & 25.164 & & & 2703072 & 3124393 \\
L-Sistin & 26.989 & 100 & 121.16 & 175701 & \\
L-Tirosin & 27.255 & 100 & 181.19 & 2608972 & 5092221 \\
L-Valin & 28.239 & 100 & 117.15 & 3458352 & 10476322 \\
L-Metionin & 28.687 & 100 & 149.21 & 3050629 & 889311 \\
L-Lisin & 30.843 & 100 & 182.65 & 1913685 & 2216487 \\
L-Isoleusin & 31.594 & 100 & 131.18 & 4575919 & 5656498 \\
L-Leusin & 32.041 & 100 & 131.18 & 4855021 & 12824760 \\
L-Phenil alanin & 32.892 & 100 & 165.19 & 6473654 & 15870086 \\
\hline
\end{tabular}




\section{SIMPULAN}

Berdasarkan hasil penelitian yang telah dilakukan dapat disimpulkan : 1) Hasil analisis profil protein dari sarang burung wallet (Collocalia fuciphaga) menggunakan SDSPAGE dengan konsentrasi akrilamida $12 \%$ didapat 6 pita protein dengan bobot molekul masing-masing $147,2 \mathrm{kDa} ; 142,6 \mathrm{kDa} ; 133,4$ $\mathrm{kDa} ; 73,3 \mathrm{kDa} ; 66,2 \mathrm{kDa}$ dan $37,7 \mathrm{kDa} ; 2$ ) Hasil analisis kadar protein sarang burung wallet (Collocalia fuciphaga) menggunakan metode semi mikro kjeldahl adalah 55,62\%;3) Hasil analisis asam amino sarang burung wallet (Collocalia fuciphaga) menggunakan KCKT didapatkan 7 asam amino essensial yaitu histidin (2,309\%), Leusin $(3,839 \%)$, Treonin $(3,819 \%)$, Valin $(3,931 \%)$, Metionin $(0,482 \%)$, Isoleusin $(1,796 \%)$, Fenil alanine $(4,486 \%)$ dan 9 asam amino non essensial yaitu Asam Serin (4,556\%), aspartate (4.480\%), Arginin (3.929\%), Lisin (2.343\%), Prolin $(3.637 \%)$, Asam glutamate $(3.647 \%)$, glisin (1.868\%), Alanin (1.309\%), Tirosin (3.918\%).

\section{DAFTAR PUSTAKA}

Abidin, F.Z., Hui, C.K., Luan, N.S., Ramli, E.S. M., Hun, L.T., and Ghafar, N.A., 2011, Effects of Edible Birds Nest (EBN) on Cultured Rabbit Corneal Keratocytes, BMC Complementary and Alternative Medicine., 11: 94.

Aswir, A.R., and Wan, Nazaimoon, M., 2010, Effect of Edible Bird's Nest on Caco-2 Cell Proliferation, J. Food Technol., 8(3): 126 130.

Chan, S.W., 2010, Review of Scientific Research on Edible Bird's Nest. Review-Scientific. Departement of Applied Biology and Chemical Technology, The Hong Kong Polytechnic University.

Coligan, J.E., Dunn, B.M., Ploegh, H.L., Speicher, D. W., and Wingfield, P. T., 1997, Current Protocols in Protein Science., Vol 1. Jhon Wiley \& Sonns Inc. USA.

Colombo, J.P., Garcia-Rodenas, C., Guesry, P.R., and Rey, J., 2003, Potential effects of supplementation with amino acids, choline or sialic acid on cognitive development in young infants, Acta Pediatr. Suppl,, 46: 92.

Kathan, R.I.I., and Weeks, D.I., 1969, Structure studies of collocalia mucoid I, Carbohydrate and amino acid composition, Arch. Biochem. Biphys., 134: 572-576.

Latupeiressa, S.B., Hadi, H., dan Susilowati, 2000, Perilaku Ibu Hamil Kurang Energi Kronik dalam Program Pemberian Makanan Tambahan Pemulihan di Kecamatan Wates dan Temon N Kabupaten Kulon Progo, Sains Kesehatan 13: 1-14.

Liu, X., Lai, X., Zhang, S., Huang, X., Lan, Q., Li, Y., Li, B., Chen, W., Zhang, Q., Hong, D., and Yang, G., 2012, Proteomic Profile of Edible Birds Nest Proteins, J. Agric. Food Chem., 60: 12477 - 12481.

Marcone, M.F., 2005, Characterization of the Edible Bird's the "Caviar of the East", Food Res Int., 38: 1125 - 1134.

Mardiastuti, A., 1997, Pemanfaatan Sarang Burung Walet Secara Lestari, Makalah pada Seminar Pendayagunaan Potensi Burung untuk Meenunjang Pembangunan Nasional, Fakultas Kehutanan Institut Pertanian Bogor.

McDonald, C.E., 1977, Methos of Protein Analysis and Variation in Protein Results, Farm Research., 5-6.

Menefee, S.G., and Overman, O.R., 1940, A Semi micro Kjeldahl Methods for the Determination of Total Nitrogen in Milk, Journal of Dairy Science., 23(12): 11771185.

Ng, M.H., Chan, K.H., Kong, Y.C., 1986, Potentiation of mitogenicity response by extracts of swiftlet's (Collocalia) nets, Biochem. Int., 13:521-531.

Qin, Y.Y., Liang, X., Hua, W., and Xing, Z., 2000, Determination of Edible Bird's Nest and Its Products by Gas Chromatography, J. Chrom Sci., 38.

Ramli, N., and Azmi, S.M.N., 2012, Food Safety Governance: Standard Operating Procedure on Controlling of Nitrite Level, Handling and Processing of Edible Bird's Nest, Aust J. Basic appl Sci., 6(11): $301-305$.

Roh, K.B., Lee, J., Kim, Y.S., Park, J., Kim, J.M., Lee, J., and Park, D., 2012, Mechanism of Edible Bird's Nest Extract - Induced Proliferation of Human Adipose - Derived Stem Cells, Evidence - Based Complementary and Alternative Medicine.

Rutherfurd, S.M., and Dunn, B.M., 2011, Quantitative Amino Acid Analysis. Curr Protoc Protein Sci. Chapter 3: unit 3:2. John Wiley \& Sons., Inc. Doi:10.1002/0471140864. 
Sumarno, S., Noegrohati, Narsito, I. I., dan Falah, 2002, Estimasi Kadar Protein Dalam Bahan Pangan Melalui Analisis Nitrogen Total dan Analisis Asam Amino, Majalah Farmasi Indonesia., 13(1): 34-43.

Utami, F., 2012, Analisis Profil Protein dan Asam Amino Tinta Cumi-Cumi Loligo pealei Lesueur Menggunakan Metode SDS-PAGE dan KCKT Serta Uji Aktivitas Antibakterinya, Skripsi, Program Studi Farmasi Fakultas Kedokteran dan Ilmu Kesehatan Universitas Islam Negeri Syarif Hidayatullah Jakarta.

Zaenab, H., Nur, Hulwani I., Sarojini, 2013, Journal of Asian Scientific Research., 3(6): 600-607. 
